\title{
Integrating Gender and Development (GAD) in the Classroom: The Case of Lucsuhin National High School, Department of Education-Philippines
}

\section{Thessa A. Hernandez and Mario A. Cudiamat}

Teacher 2, Senior High School in Calatagan, Department of Education-Batangas

Master Teacher 2, Senior High School in Calatagan, Department of Education-Batangas

\section{Abstract}

The integration of gender-sensitive teaching strategy remains to be a challenge among educators. This social issue requires more in-depth exploration especially in the classroom to promote its significance and determine its applicability and effectiveness. This study aimed to apply the Gender and Development (GAD)

Corresponding Author: Thessa A. Hernandez thessa.hernandez@ deped.gov.ph

Received: 23 April 2018 Accepted: 8 May 2018 Published: 4 June 2018

Publishing services provided by Knowledge $\mathrm{E}$

(c) Thessa A. Hernandez and Mario A. Cudiamat. This article is distributed under the terms of the Creative Commons

Attribution License, which permits unrestricted use and redistribution provided that the original author and source are credited.

Selection and Peer-review under the responsibility of the IRCHE 2017 Conference Committee.

\section{G OPEN ACCESS} approach in teaching Filipino Literature among Grade 8 learners. It specifically employed gender-based differentiated instruction (GBDI). GBDI pertains to a teaching approach where the teacher assigns group to students based on their gender, multiple intelligences and learning style. Quasi-experimental research design was used to assess the academic performance of the students while correlated t-test for the comparison of the pre-test and posttest result of the students. This study revealed that there is an increase in the pre-test scores when the students were exposed to the gender-sensitive teaching approach. The learners are also encouraged based on the interviews and observation conducted. The study suggests the gender-responsive teaching approach be integrated in the classroom to promote gender equality and contribute to the improvement of learner's academic performance.

Keywords: gender equality, awareness, GBDI, gender-sensitive, academic performance

\section{Introduction}

School is one of the places, which shows gender issues. Many studies show different matters of discrimination, both of boys and girls, and many amount of adjustment is still needed if equality between or equal opportunities especially the strategies to be used. It is really a big challenge to teachers to cater the different needs of the students. Sometimes teachers forget to give importance to the gender of her students. The aim 
of this research is to shed light on the classroom situations in Filipino class that will focused in Gender-based Differentiated Instruction.

According to Gumba (2013), in almost every aspect of the Philippine educational system, women and girls outnumber men and boys (United Nations, 2011). [1] The 2008 Functional Literacy, Education and Mass Media Survey (National Statistical Coordination Board, 2010) showed that the basic literacy rate among females is $96.1 \%$ while 95.1\% among males. Functional literacy among females in the same period was also higher at $88.7 \%$ as against $84.2 \%$ among males. At public elementary level during the school year 2010-2011, female Net Enrollment Ratio (NER) was computed at $91.07 \%$ while male NER was lower at $88.78 \%$.

Consequently, female participation rate in high school also exceeded that of males at $63.53 \%$ vs. $53.65 \%$.

As educators or parents or just as adults, we all acknowledge that there are differences between boys and girls as well as differences between women and men. There is discourse these days about whether or not the differences are a result of nature or nurture. As classroom teachers, the nature v. nurture debate is not that relevant to us. What is relevant is that teacher see gender differences in the students in our classrooms.

[2] An important part of these daily challenges has to do with gender. It's not the same to teach co-ed classes than only girls' or boys', there is a lot going on inside those little heads which we still don't fully understand. New studies are being done to help us learn more about our students' needs in order to reach them accordingly and field experts have proved that boys and girls learn in a different way just because of gender, Coniglio (2016). [3] According to Sax (2005) with gender-based instruction, it has been important for educators and parents to understand that it is taking what we already know about how boys and girls learn and using it for the child's advantage. It would mean engaging girls in math, science, and technology, while promoting reading and writing with "boy friendly" literature in the classroom. Gender based classrooms are not intended to have a different curriculum for boys and girls. It is not giving preference for one gender over another and it is not segregation.

[4] Chadwell (2007) suggested that teachers must recognize the energy that boys bring to the classroom as a learning opportunity instead of behavior that needs to be controlled. Here are two strategies for working with boys:

- Put boys to work after providing them with an abbreviated, bulleted set of instructions. 
- Have them answer questions after 10 minutes of work.

- Use problem-based learning. Start units or lessons with an essential question involving decisions or choices.

- Teachers must delight in the richness of girls, and accept their tendency to please the teacher, all while appropriately channeling their desire to please during discussions, lessons, or units.

Here are three strategies for working with girls:

- Take time to explain instructional processes, answer their questions, consider their suggestions, and probe their hypotheses.

- Use project-based learning. Embed units and lessons with connections to the real world, and show relationships between the content/skills and the lives of real people.

\section{Objectives of the Study}

This research study assessed the effects of gender-based differentiated instruction on the academic performance of Grade 8 students in Filipino of Lucsuhin National High School.

Specifically, the study sought answers to the following questions: (1) What is the perception of the learners on the gender-based differentiated? (2). How significant is the difference between the pre-test and post scores in Filipino of the respondents? (3) Is there a significant relationship on the respondents' profile variables and academic performance using GBDI?

\section{Materials and Methods}

\subsection{Sampling}

This study utilized both descriptive and experimental research design. In the context of experimental set up, a pre-test and post-test group design was employed. The respondents composed of (48) forty-eight Grade 8 learners who are average in terms of academic performance. The researcher prefers this group of respondents due to their active participation in the previous class. These group is composed of (24) twenty-four males and (24) twenty-four females with a total of (48) forty-eight learners. 


\subsection{Data collection}

The researchers constructed two sets of questionnaire. The first set of questionnaire represents the pre-test and post-test to determine the academic performance of the Grade 8 learners. The pre-test and post-test includes localization and contextualization of gender-sensitive situations in the Filipino society and culture.

On the other hand, the second set of questionnaire assessed the perception and impact of gender-based differentiated instruction on the students. It has two parts: personal data which requires the respondents to fill in their name (optional), section, age, gender and daily allowance; the perception of the learners on the impact of Gender-based Differentiated Instruction on their learning. The perception part of the questionnaire has (6) six indicators: general attitude, learning achievements, learning achievements, learning environment, student's involvement, values formation and gender equality. Validity and reliability were done to check the content and internal consistency by the test items. Statistical Package for the Social Sciences (SPSS) was employed for the reliability after the pilot testing of the instruments.

\subsection{Ethical issues}

Before conducting this study, the researcher requested permission from the Secondary School Principal IV through the assistance of the Head Teacher in Filipino in order to smoothly gather the much needed data and information in solving the problems posted in this study. A letter of consent for the student-respondents and their parents was also attached in the questionnaire for ethical consideration. The researcher assured that the data and research of the study will be treated confidentially and will be used for research purposes for the improvement of teaching and learning process.

\section{Results and Discussion}

This part of the study embodies actual data of the study. It analyses the data and interprets the finding of the study.

Table 1 shows that "Working with a partner or group to complete class work" rank first with a mean of 4.73 and SD which is 0.49 , rank 2 is "students became more

motivated to attend Filipino class when GBDI was used" with a of 4.42 and SD which is 0.50 . Last is "gender based differentiated instruction gives more opportunity to 
Table 1: Students' Perception to Gender-based Differentiated Instruction as to Classroom Involvement.

\begin{tabular}{|c|c|c|c|c|}
\hline $\begin{array}{c}\begin{array}{c}\text { Student's Classroom } \\
\text { Involvement }\end{array} \\
\end{array}$ & Mean & SD & Interpretation & Rank \\
\hline $\begin{array}{l}1 \text { Working with a partner or group to } \\
\text { complete class work }\end{array}$ & 4.73 & 0.49 & Strongly Agree & 1 \\
\hline $\begin{array}{l}\text { 2. I was more motivated to attend } \\
\text { Filipino class when GBDI was used }\end{array}$ & d 4.42 & 0.50 & Strongly Agree & 2 \\
\hline $\begin{array}{l}\text { 3. Gender based differentiated } \\
\text { instruction gives more opportunity } \\
\text { to showcase my hidden talent.. }\end{array}$ & 4.06 & 0.63 & Agree & 3 \\
\hline \multicolumn{5}{|c|}{4.40} \\
\hline Weighted Mean & & & Strongly Agree & \\
\hline
\end{tabular}

showcase my hidden talent" with a mean of 4.06 and SD which is 0.63 . In general, students is Strongly Agree on their perception on classroom involvement using GBDI.

Data shows that classroom involvement is needed to improve students' academic performance.

TABle 2: Students' Perception to Gender-based Differentiated Instruction as to Values Formation.

\begin{tabular}{lcclc}
\hline \multicolumn{1}{c}{ Values Formation } & Mean & SD & Interpretation & Rank \\
\hline $\begin{array}{l}\text { 1. I respect opinions views of } \\
\text { my classmates on certain topics } \\
\text { during discussion. }\end{array}$ & 4.69 & 0.51 & Strongly Agree & 2 \\
$\begin{array}{l}\text { 2. I learn to think negative and } \\
\text { positive impact of opinion } \\
\text { during group discussion. }\end{array}$ & 4.63 & 0.49 & Strongly Agree & 3 \\
$\begin{array}{l}\text { 3. I learn to socialize well with } \\
\text { my classmates }\end{array}$ & 4.81 & 0.39 & Strongly Agree & 1 \\
\multicolumn{1}{c}{ Weighted Mean } & $\mathbf{4 . 7 1}$ & & & \\
\hline
\end{tabular}

Table 2 shows that the weighted mean is 4.71 with an interpretation of Strongly

Agree on the student's perception to GBDI according to their values formation. Data shows that GBDI has an implication on student's values formation.

Table 3 shows that equal opportunity should be given to everyone regardless on their gender with a mean of 4.81 and the SD is 0.45 followed by giving equal treatment to male and female classmates with an mean of 4.75 and the SD is 0.44 . The weighted mean is 4.78 with an interpretation of Strongly Agree.

The result shows that the academic performance of the students after using genderbased differentiated instruction, the respondents' pre-test mean is 22.63 while the 
TABLE 3: Students' Perception to Gender-based Differentiated Instruction as to Gender Equality.

\begin{tabular}{lcclc}
\hline \multicolumn{1}{c}{ Gender Equality } & Mean & SD & Interpretation & Rank \\
\hline $\begin{array}{l}1 . \quad \text { There should be } \\
\text { equal treatment to my } \\
\text { male and female } \\
\text { classmates }\end{array}$ & 4.75 & 0.44 & Strongly Agree & 2 \\
$\begin{array}{l}\text { 2. Equal opportunity } \\
\text { should be given to } \\
\text { everyone regardless on } \\
\text { their gender. }\end{array}$ & 4.81 & 0.45 & Strongly Agree & 1 \\
$\quad \begin{array}{l}\text { Weighted Mean } \\
\quad\end{array}$ & $\mathbf{4 . 7 8}$ & & Strongly Agree & \\
\hline
\end{tabular}

TABLE 4: Significant Difference of Pre-test and Post test Results in Filipino by the Students.

\begin{tabular}{|c|c|c|c|c|c|c|}
\hline \multirow{2}{*}{$\begin{array}{c}\text { Academic } \\
\text { Performance }\end{array}$} & \multirow[t]{2}{*}{ Mean } & \multirow[t]{2}{*}{$\mathrm{N}$} & \multirow{2}{*}{$\begin{array}{l}\text { df (degrees } \\
\text { of } \\
\text { freedom) }\end{array}$} & \multicolumn{2}{|c|}{$\mathrm{t}$-value } & \multirow{2}{*}{ Interpretation } \\
\hline & & & & Computed & Tabular & \\
\hline Pre-test & 22.63 & \multirow[b]{2}{*}{48} & \multirow[b]{2}{*}{47} & \multirow[b]{2}{*}{-2.3032} & \multirow[b]{2}{*}{2.0117} & \multirow{2}{*}{$\begin{array}{c}\text { Significant at } \\
p<0.05\end{array}$} \\
\hline Post test & 36.81 & & & & & \\
\hline
\end{tabular}

posttest mean is 36.81 . The degrees of freedom (df) is 47 . The computed t-value is -2.3032 with a tabular value of 2.0117 where in the interpretation is There is a

Significant Difference The mean of posttest is higher than the pre-test. Data proved that there is an increase on the pretest and posttest of the students using GBDI. The findings is supported by the t-test that shows that the computed t-value is higher than the tabular t-value which 0.05 level of significance. The use of GBDI in teaching Filipino helps to improve the academic performance of students in Lucsuhin National High School.

TABLE 5: Significant Relationship of Respondents' Profile Variables and their Academic Performance using GBDI.

\begin{tabular}{ccccccc}
\hline $\begin{array}{c}\text { Profile } \\
\text { Variable }\end{array}$ & r- Value & $\begin{array}{c}\text { Degree of } \\
\text { freedom }\end{array}$ & $\begin{array}{c}\text { Level of } \\
\text { Significance }\end{array}$ & $\begin{array}{c}\text { r- Tabular } \\
\text { Value }\end{array}$ & Interpretation & Decision \\
\hline Age & -0.03348 & 46 & 0.05 & 0.2845 & $\begin{array}{c}\text { No Significant } \\
\text { Relationship }\end{array}$ & $\begin{array}{c}\text { ACCEPTED } \\
\text { Ho }\end{array}$ \\
Gender & -0.03216 & 46 & 0.05 & 0.2845 & $\begin{array}{c}\text { No Significant } \\
\text { Relationship }\end{array}$ & $\begin{array}{c}\text { ACCEPTED } \\
\text { Ho }\end{array}$ \\
$\begin{array}{c}\text { Daily } \\
\text { Allowance }\end{array}$ & -0.00450 & 46 & 0.05 & 0.2845 & $\begin{array}{c}\text { No Significant } \\
\text { Relationship }\end{array}$ & $\begin{array}{c}\text { ACCEPTED } \\
\text { Ho }\end{array}$ \\
\hline
\end{tabular}

Table 5 shows that the r- value according to age is -0.03348 while -0.0326 is the $r$ - value according to gender and -0.00450 is the r-value according to daily allowance. The three profile variables have degree of freedom of 46 , level of significance which is 0.05 and the r- Tabular Value is 0.2845 . The three profile variables have also the same interpretation which is "No Significant Relationship" and the decision is "Accepted Ho". 
This means that there is no significant relationship on the respondents' profile variables and their academic performance.

\section{Conclusion and Recommendation}

1. The strongly agree that gender-based differentiated instruction affects their learning.

2. There is a significant difference on the result of pre-test and post test in Filipino after using GBDI.

3. There is no significant relationship on the profile variables of the respondents and their academic performance.

1. Gender-based differentiated instruction is highly recommended to be used in other subject area.

2. Teachers must use different teachings strategies that caters the talent and learning needs of every student.

3. Because there is no significant relationship on the profile variables of the respondents and their academic performance, the researchers highly recommended that teachers must be sensitive and conscious on the different aspects that affect the academic performance of the students.

\section{Author's Note}

This contains the following Information which may already be shown/footnoted in the first page of the manuscript: (1) author/s' full name and affiliation/s (department and institution); (2) acknowledgements (of persons, groups, organizations who provided technical and/or financial aid); (3) disclaimers (e.g., statement on conflict of interest); and (4) contact details of the corresponding author.

\section{Appendix}

Appendixes, if needed, appear before the references.

\section{References}




\section{Strictly follow the numbered format of citation while observing the proper APA style of referencing.}

[1] Gumba, B.M. (2013) Gender Equality in a Higher Educational Institution: A Case in the Philippines, Ateneo De Naga University

[2] Coniglio, R. (2010) Why Gender Matters in Differentiating Instruction, http://www. teachhub.com/why-gender-matters-differentiating-instruction

[3] Sax, L. (2005). Why gender matters: what parents and teachers need to know about the emerging science of sex differences. New York, NY: DoubledAY

[4] Chadwell, David, "Engaging the Differences Between Boys and Girls" Middle Matters, Vol. 15, No. 4, March 2007. 